\section{Mortality from Alzheimer's disease in Brazil, 2000-2009}

\author{
Doença de Alzheimer: estudo da mortalidade no \\ Brasil, 2000-2009
}

\author{
Enfermedad de Alzheimer: estudio de la \\ mortalidad en Brasil, 2000-2009
}

Jane Blanco Teixeira 1

Paulo Roberto Borges de Souza Junior 2 Joelma Higa 3

Mariza Miranda Theme Filha ${ }^{1}$

\footnotetext{
${ }^{1}$ Escola Nacional de Saúde Pública Sergio Arouca,

Fundação Oswaldo Cruz, Rio de Janeiro, Brasil.

2 Instituto de Comunicação

e Informação Científica

e Tecnológica em Saúde.

Fundação Oswaldo Cruz, Rio

de Janeiro, Brasil.

3 Pontifícia Universidade

Católica de São Paulo, São

Paulo, Brasil.

Correspondence

M. M. Theme Filha

Departamento de

Epidemiologia e Métodos

Quantitativos em Saúde,

Escola Nacional de Saúde

Pública Sergio Arouca,

Fundação Oswaldo Cruz.

Rua Leopoldo Bulhões 1480

$8^{\circ}$ andar, Rio de Janeiro, $R J$

21041-210, Brasil.

marizatheme@hotmail.com
}

\begin{abstract}
Alzheimer's disease is the most prevalent type of dementia in the elderly worldwide. To evaluate the mortality trend from Alzheimer's disease in Brazil, a descriptive study was conducted with the Mortality Information System of the Brazilian Ministry of Health (2000-2009). Age and sexstandardized mortality rates were calculated in Brazil's state capitals, showing the percentage variation by exponential regression adjustment. The state capitals as a whole showed an annual growth in mortality rates in the 60 to 79 year age bracket of $8.4 \%$ in women and $7.7 \%$ in men. In the 80 and older age group, the increase was $15.5 \%$ in women and $14 \%$ in men. Meanwhile, the all-cause mortality rate declined in both elderly men and women. The increase in mortality from Alzheimer's disease occurred in the context of chronic diseases as a proxy for increasing prevalence of the disease in the population. The authors suggest healthcare strategies for individuals with chronic non-communicable diseases.
\end{abstract}

Alzheimer Disease; Dementia; Aged; Mortality

\section{Resumo}

A doença de Alzheimer é o tipo de demência que mais prevalece entre os idosos no mundo. Para avaliar a evolução da mortalidade por doença de Alzheimer no Brasil foi desenvolvido um estudo descritivo com os dados do Sistema de Informações sobre Mortalidade do Ministério da Saúde, no período de 2000 a 2009. Calcularam-se as taxas de mortalidade padronizadas por idade e sexo nas capitais brasileiras e se observou a variação percentual por meio de ajuste por regressão exponencial. Para o conjunto das capitais houve um crescimento anual nas taxas de mortalidade na faixa etária de 60 a 79 anos de $8,4 \%$ entre as mulheres $e$ 7,7\% entre os homens. No grupo etário de 80 anos e mais, o aumento foi de $15,5 \%$ entre as mulheres e $14 \%$ entre os homens. Contrariamente, verificou-se declínio da taxa de mortalidade por todas as causas entre os idosos em ambos os sexos. Destaca-se o aumento da mortalidade por doença de Alzheimer no contexto das doenças crônicas como um indicador aproximado da prevalência da doença na população, e são apontadas estratégias de assistência ao cuidado dos portadores de doenças de longa duração.

Doença de Alzheimer; Demência; Idoso; Mortalidade 


\section{Introduction}

Rapid aging of the Brazilian population in recent decades, the result of the demographic transition, produced a change in the country's age pyramid, with an increase in life expectancy. The demographic transition has been paralleled by a change in morbidity and mortality patterns, with a predominance of non-communicable diseases and conditions (NCDs). Cardiovascular and neuropsychiatric diseases have taken a leading place, rapidly becoming a public health problem, particularly dementias, with a major impact on the elderly population 1,2 .

Dementia from Alzheimer's disease accounts for $60 \%$ of all dementias and is the most prevalent form of dementia worldwide 3. Currently, 35.6 million people live with the disease, and it is estimated that this number will double every 20 years, reaching 65.7 million in 2030 4 . Alzheimer's disease is the leading cause of functional dependency, institutionalization, and mortality among the elderly population 5 and is associated with various risk factors such as cardiovascular diseases, obesity, diabetes, and hyperlipidemia 6,7 . In addition to these factors, age, gender, low schooling, depression, and genetic alterations may account for the increase in incidence of the disease 8,9,10.

For the diagnosis of Alzheimer's disease in Brazil, the current guidelines of the Scientific Department for Cognitive Neurology and Aging of the Brazilian Academy of Neurology specify the presence of at least two of the following cognitive or behavioral symptoms, affecting at least two of the following domains: memory, executive functions, visual and spatial skills, language, and personality or behavior. The following are considered exclusion criteria: major cerebrovascular disease, central characteristics of dementia with Lewy's bodies (visual hallucinations, Parkinsonism, and cognitive fluctuation), and frontotemporal dementia, evidence of another concurrent and active disease (neurological or non-neurological), or use of medication that can have a substantial effect on cognition 11.

Survival after diagnosis of the disease depends heavily on age at onset of symptoms. Median survival time varies from 8.3 years when the diagnosis is made close to 65 years and 3.4 years when it is made later, after 90 years of age. Diagnosis of Alzheimer's disease between 65 and 90 years is associated with a reduction of $67 \%$ and $39 \%$, respectively, in life expectancy 12 . In addition to age, other factors have been identified as predictors of survival, such as gender and the degree of functional and cognitive impairment 13 .

While several countries have reported a drop in mortality rates from other chronic diseases such as stroke and cardiovascular diseases 14,15, the mortality trend from Alzheimer's disease has increased consistently in both genders and in the age brackets above 60 years 16,17, and this increase is apparently not related only to improvement in diagnostic capacity 18 , but also to the population's greater longevity 2 .

There are few studies in Brazil on morbidity and mortality from Alzheimer's disease. Most of the studies address dementias in general or are limited to small samples, usually in hospital units, nursing homes, or socioeconomically differentiated groups 19,20. The scarcity of Brazilian data represents a gap in knowledge on the epidemiological profile of Alzheimer's disease in the country, despite its known impact on patients, families, and caregivers 21 .

The objective of this study is to describe the trend in the mortality rate from Alzheimer's disease in Brazil from 2000 to 2009, using population-based data, based on the Mortality Information System (SIM) of the Health Informatics Department (DATASUS). This analysis is expected to contribute to a broader understanding of the problem, supporting specific measures for comprehensive and inter-sector care for persons with Alzheimer's disease.

\section{Methods}

A descriptive, retrospective, times-series study was conducted on the trend in mortality rate from Alzheimer's disease in Brazil's state capitals from 2000 to 2009.

The state capitals in the North (Rio Branco, Porto Velho, Manaus, Belém, Boa Vista, Macapá, and Palmas), Northeast (São Luís, Teresina, Fortaleza, Natal, João Pessoa, Recife, Maceió, Aracaju, and Salvador), and Central (Campo Grande, Cuiabá, and Goiânia, excluding Brasília) were grouped as analytical units due to the small number of cases, which caused major instability in the indicator. The state capitals in the Southeast and South were analyzed separately. Only the state capitals were included, due to their better coverage and quality of information. Information is faulty on deaths outside the capitals in most of the states, as shown by Szwarcwald et al. 22 when estimating coverage of births and deaths in Brazil's municipalities.

The definition of death from Alzheimer's disease was based on its inclusion as the underlying cause of death on the Death Certificate (DC), and death with Alzheimer's disease when it was recorded anywhere on the DC, considering codes G30.0 to G30.9 of the International Classification of Diseases, 10th revision (ICD-10). 
Mortality rates were calculated using the number of deaths recorded in the SIM database and data from the population censuses from 2000 to 2010, published by the Brazilian Institute of Geography and Statistics (IBGE). The populations were estimated for the inter-census years based on the mean annual growth rates, using geometric interpolation.

Initially, we calculated the standardized mortality rates per 100,000 inhabitants with Alzheimer's disease as the underlying cause or other recorded cause for all the Brazilian state capitals, considering the population 60 years and older. Standardization used the 2010 population census.

Ages were grouped in two categories (60 to 79 years and 80 years and older) due to the small number of deaths from Alzheimer's disease in individuals under 80 years of age.

For each age group (60 to 79 years and 80 and older), sex, and state capital or set of capitals, we calculated the specific mortality rates and percent annual variation, with exponential regression adjustment to the mortality rates with Alzheimer's disease mentioned, for the years 2000 to 2009.

Scatterplots were constructed for the mortality rates in the target years to visualize the type of relationship between them. Next, in order to assess the trend in mortality rates, curves were estimated with mortality rate as the dependent variable and year as the independent variable. Exponential regression was used because the angle regression coefficient represents the percentual annual variation in mortality rates in the study period and all the estimated curves showed a high coefficient of determination ( $\left.\mathrm{R}^{2}\right)$.

In order to know the causes of death in persons with Alzheimer's disease, we calculated the proportional distributions of the principal underlying causes in the 60 and older age bracket, according to presence or absence of Alzheimer's disease. To test the difference between proportions, we used the chi-square test and respective p-value, with significance level at $5 \%$.

The data were analyzed with SPSS, version 17.0 (SPSS Inc., Chicago, USA).

\section{Results}

From 2000 to 2009, the SIM recorded 1,505,326 deaths in the population 60 years and older in Brazil's state capitals, of which $0.4 \%$ had Alzheimer's disease as the underlying cause and $0.8 \%$ as cause recorded anywhere on the DC. Considering mortality from diseases of the central nervous system in 2009, Alzheimer's disease coded as the underlying cause of death accounted for $65 \%$ of the deaths in women and $51.1 \%$ in men.

As shown in Table 1, there was a constant increase in mortality rates in Brazil's state capitals

Standardized mortality rate (per 100,000 inhabitants) with Alzheimer's disease as the underlying cause or cause recorded anywhere on the Death Certificates in the population 60 years and older. State capitals of Brazil, 2000-2009.

\begin{tabular}{|c|c|c|c|c|c|c|c|c|}
\hline \multirow[t]{2}{*}{ Year } & \multicolumn{4}{|c|}{ Men } & \multicolumn{4}{|c|}{ Women } \\
\hline & Deaths * & $\begin{array}{c}\text { Mortality } \\
\text { rate * }\end{array}$ & Deaths ** & $\begin{array}{c}\text { Mortality } \\
\text { rate ** }\end{array}$ & Deaths * & $\begin{array}{c}\text { Mortality } \\
\text { rate * }\end{array}$ & Deaths ** & $\begin{array}{c}\text { Mortality } \\
\text { rate ** }\end{array}$ \\
\hline 2000 & 251 & 19.9 & 384 & 30.4 & 420 & 21.4 & 655 & 33.4 \\
\hline 2001 & 279 & 20.6 & 490 & 36.3 & 558 & 27.4 & 896 & 40.0 \\
\hline 2002 & 355 & 25.0 & 571 & 40.5 & 658 & 30.7 & 1,078 & 50.4 \\
\hline 2003 & 432 & 29.6 & 698 & 47.7 & 732 & 32.7 & 1,198 & 53.5 \\
\hline 2004 & 507 & 33.5 & 879 & 57.9 & 985 & 42.0 & 1,601 & 68.2 \\
\hline 2005 & 597 & 37.2 & 1,038 & 64.3 & 1,183 & 47.4 & 1,988 & 75.8 \\
\hline 2006 & 738 & 43.9 & 1,170 & 69.3 & 1,507 & 57.4 & 2,396 & 91.4 \\
\hline 2007 & 796 & 45.0 & 1,303 & 73.7 & 1,697 & 61.5 & 2,705 & 98.1 \\
\hline 2008 & 927 & 50.8 & 1,479 & 81.0 & 1,899 & 66.2 & 3,038 & 106.0 \\
\hline 2009 & 1,003 & 52.8 & 1,683 & 88.5 & 2,039 & 67.9 & 3,361 & 112.0 \\
\hline Annual variation (\%) & - & 11.7 & - & 11.8 & - & 13.2 & - & 13.8 \\
\hline$p$-value & - & $<0.001$ & - & $<0.001$ & - & $<0.001$ & - & $<0.001$ \\
\hline
\end{tabular}

* Alzheimer's disease as underlying cause;

** Alzheimer's disease as cause recorded anywhere on the Death Certificates. 
as a whole during the study period, whether Alzheimer's disease was recorded as the underlying cause or as cause recorded anywhere on the DC. In men, the mean annual increase in mortality from Alzheimer's disease was $11.7 \%$ as the underlying cause and $11.8 \%$ as cause recorded anywhere on the DC. In women, the increase was $13.2 \%$ and $13.8 \%$, respectively, for underlying cause and cause recorded anywhere on the DC. Importantly, mortality rates were significantly higher when they included Alzheimer's disease as cause recorded anywhere on the DC.

The time trend in mortality with Alzheimer's disease in Brazil's state capitals showed increasing rates in men and women in both age groups. Meanwhile, the trend in all-cause mortality rates declined in both sexes, both in the 60-79 and 80-and-older groups (Table 2).

Tables 3 and 4 show the increase in mortality rates when analyzing each geographic unit separately (state capitals or sets of capitals in the geographic regions), according to sex and age bracket. In women, the highest annual growth rates were in the North, Northeast, and Central regions and in the national capital Brasília, in both age brackets, and the increase was statistically significant. Florianópolis was the only state capital that did not show a significant increase in individuals less than 80 years of age (Table 3 ).

A similar trend was seen in men, but the annual variations were smaller in the state capitals in the South of Brazil. Curitiba and Porto Alegre only showed a statistically significant variation in the population 80 years and older (Table 4 ).

As for the underlying cause of death in the study population, diabetes mellitus and stroke were significantly higher in those with Alzheimer's disease recorded on the DC, when compared to those without the disease, in both sexes ( $\mathrm{p}<$ 0.001 ). In men, respiratory diseases and ischemic heart diseases did not show differences between the two groups, and neoplasms were more frequent in individuals without Alzheimer's disease. In women, except for respiratory diseases and neoplasms, all others diseases were significantly more frequent in persons with Alzheimer's disease $(p \leq 0.001)$ (Table 5).

\section{Discussion}

This is the first nationwide study on mortality from Alzheimer's disease in Brazil. The findings show constant and significant annual increases in mortality rates in elderly individuals 60 years and older, in both sexes, and in the various regions of the country. This same trend has been observed in other countries in recent decades.
Moschetti et al. 23 analyzed the time trend in mortality from Alzheimer's disease in the United States from 1999 to 2008 and found a 5\% increase in the age-adjusted mortality rate, which was directly proportional to age. The oldest elderly showed systematically higher mortality rates. Among the ten main causes of death in the elderly, the highest increase was seen in the adjusted rate for Alzheimer's disease (43\% variation), and only renal diseases and suicide also showed positive growth (13\% in both cases).

The same trend was found in a study on all regions of France in 2006 16. The growth in mortality rates from Alzheimer's disease was $14.3 \%$ in men and $10.1 \%$ in women. Alzheimer's disease as one of recorded cause on the DC accounted for $10.3 \%$ of all-cause mortality $(7 \%$ in men and $13.5 \%$ in women) and was the sixth leading cause of death in the overall population and fifth in the elderly. Although mortality rates from other causes have decreased in persons 65 years and older, mortality from Alzheimer's disease has increased, especially in those 85 years and older.

In England and Wales, from 1985 to 2004, the standardized mortality rate with mention of Alzheimer's disease increased from levels as low as 1 per 100,000 in both sexes in 1985 to 6.8 per 100,000 in men and 7.9 per 100,000 in women 20 years later. When comparing the time trend in mortality from Alzheimer's disease, dementias in general, and Parkinson's disease, only Alzheimer's disease increased significantly, while mortality from Parkinson's disease declined and mortality from other dementias remained stable 24 .

The growth pattern in mortality from Alzheimer's disease can also be seen in other Latin American countries besides Brazil. In Venezuela, a study from 1988 to 1998 showed an increase in mortality from Alzheimer's disease from 0.22 to $5.5 / 100,000$ inhabitants. In men, it increased from 0 to $4.7 / 100,000$. In the under-75 age bracket, the mortality rate was higher in men, while above 75 years it was higher in women 25 .

Interestingly, growth in mortality was higher among women, which may result from the feminization of aging in the elderly Brazilian population, since women live longer on average than men 26 . A prospective study designed to evaluate factors associated with differences between men and women in the evolution and mortality from Alzheimer's disease showed that men present more co-morbidities than women, who in turn present greater functional decline 27 . Early male mortality due to cardiovascular diseases and external causes would place women at comparatively greater risk of developing Alzheimer's disease in old age, due to their longer survival, thus explaining the higher mortality rates from the disease in women, especially over 80 years of age. 
Time trend in Alzheimer's disease-related mortality and all-cause mortality rates (per 100,000 inhabitants) by sex and age bracket. State capitals of Brazil, 2000-2009.

\begin{tabular}{|c|c|c|c|c|c|c|c|c|}
\hline \multirow[t]{3}{*}{ Year } & \multicolumn{4}{|c|}{ Men } & \multicolumn{4}{|c|}{ Women } \\
\hline & \multicolumn{2}{|c|}{$60-79$ years } & \multicolumn{2}{|c|}{$\geq 80$ years } & \multicolumn{2}{|c|}{$60-79$ years } & \multicolumn{2}{|c|}{$\geq 80$ years } \\
\hline & $\begin{array}{l}\text { Alzheimer's } \\
\text { disease }\end{array}$ & All causes & $\begin{array}{l}\text { Alzheimer's } \\
\text { disease }\end{array}$ & All causes & $\begin{array}{l}\text { Alzheimer's } \\
\text { disease }\end{array}$ & All causes & $\begin{array}{c}\text { Alzheimer's } \\
\text { disease }\end{array}$ & All causes \\
\hline 2000 & 14.3 & 37.9 & 144.5 & 127.4 & 14.3 & 22.2 & 135.5 & 101.4 \\
\hline 2001 & 18.0 & 36.2 & 166.0 & 128.3 & 18.2 & 22.5 & 182.0 & 100.3 \\
\hline 2002 & 20.0 & 35.1 & 192.7 & 126.9 & 20.7 & 22.1 & 209.1 & 101.7 \\
\hline 2003 & 21.2 & 34.4 & 235.7 & 126.0 & 19.8 & 21.5 & 233.7 & 98.1 \\
\hline 2004 & 23.0 & 33.7 & 305.1 & 125.2 & 22.0 & 21.3 & 315.3 & 96.1 \\
\hline 2005 & 26.0 & 31.5 & 335.8 & 118.6 & 26.6 & 19.8 & 363.4 & 91.4 \\
\hline 2006 & 27.0 & 30.9 & 369.3 & 117.5 & 28.7 & 19.7 & 426.0 & 91.6 \\
\hline 2007 & 28.6 & 30.2 & 393.3 & 115.5 & 29.5 & 19.2 & 464.6 & 90.5 \\
\hline 2008 & 29.9 & 30.1 & 443.0 & 117.8 & 30.2 & 19.1 & 511.1 & 90.0 \\
\hline 2009 & 29.8 & 29.6 & 504.7 & 116.1 & 31.8 & 18.7 & 540.7 & 90.3 \\
\hline $\begin{array}{l}\text { Annual variation } \\
\text { (\%) }\end{array}$ & 7.8 & -2.8 & 14.0 & -1.3 & 8.4 & -2.3 & 15.5 & -1.6 \\
\hline$p$-value & $<0.001$ & $<0.001$ & $<0.001$ & $<0.001$ & $<0.001$ & $<0.001$ & $<0.001$ & $<0.001$ \\
\hline
\end{tabular}

The burden of co-morbidities in individuals with Alzheimer's disease is known to be higher than in matched control groups without dementias. Prevalence of vascular risk factors and cardiovascular diseases is high in Alzheimer's patients. The same is true for diabetes mellitus. Leibson et al. 28 concluded that diabetes in adults increased the risk of Alzheimer's disease by $37 \%$ in women and $127 \%$ in men. Epidemiological studies have established the link between diabetes in adults and Alzheimer's disease, and both are important causes of morbidity and mortality in the elderly. These diseases appear to share common biochemical characteristics, suggesting the same pathogenic mechanism 29 .

Importantly, the decline in mortality rates from heart disease and stroke are conventionally attributed to reductions in smoking, diagnosis and treatment of hypertension and diabetes, effective drugs to control blood lipids and reduce clot formation, and overall lifestyle improvements, but they have not been associated with reduction in mortality from Alzheimer's disease 30. A cohort study in three states of the United States to determine whether there is a corresponding decrease in the incidence rate for dementia and cognitive impairment in recent years found only a marginal decline in the incidence of dementia, with no clinically significant trend in community studies, suggesting that other mechanisms are present in the development of dementias 15 .
In the current study, the geographic distribution of mortality showed a larger increase in the North, Northeast, and Central regions of Brazil. This pattern may be explained by improved access to diagnosis, as occurs with other chronic diseases. Very similar results were found in France and the United States, where the mortality rate from Alzheimer's disease increased in the less developed and border regions 16,17.

In the state capitals of Southeast Brazil (São Paulo, Belo Horizonte, Rio de Janeiro, andVitória), although there were significant increases in mortality rates from Alzheimer's disease in both sexes and age groups, the increases were lower than in the North and Northeast. The Southeast is Brazil's largest economic and trade hub, and the most economically developed region of the country. It thus has a more consolidated supply of health programs and services, trained human resources, and technological resources available to the population. The lowest variation in the mortality rate from Alzheimer's disease in Brazil was in Florianópolis in the South and may have been due to the city's small population, causing instability in the indicator.

Mortality from Alzheimer's disease may be increasing at a time when the control of various risk factors for non-communicable chronic diseases has reduced the mortality from cardiovascular diseases, stroke, and cancer. Although the latter are still the leading causes of death in 
Mortality rate in women (per 100,000 inhabitants) with Alzheimer's disease recorded on the Death Certificate and percent annual variation by age groups and state capitals. Brazil, 2000-2009.

\begin{tabular}{|c|c|c|c|c|c|c|c|c|c|c|c|c|}
\hline Capitals/Regions & 2000 & 2001 & 2002 & 2003 & 2004 & 2005 & 2006 & 2007 & 2008 & 2009 & $\begin{array}{c}\text { Annual } \\
\text { variation } \\
\text { (\%) }\end{array}$ & $\mathrm{p}$-value \\
\hline \multicolumn{13}{|c|}{ State capitals in the North } \\
\hline 60-79 years & 5.0 & 3.8 & 6.3 & 4.3 & 12.4 & 12.3 & 13.9 & 13.3 & 15.4 & 14.8 & 16.3 & 0.001 \\
\hline$\geq 80$ years & 30.4 & 51.5 & 65.1 & 56.5 & 53.5 & 139.3 & 216.8 & 221.4 & 187.9 & 324.6 & 25.1 & $<0.001$ \\
\hline \multicolumn{13}{|l|}{ State capitals in the } \\
\hline \multicolumn{13}{|l|}{ Northeast } \\
\hline 60-79 years & 11.1 & 13.3 & 13.3 & 14.4 & 17.0 & 23.1 & 25.3 & 23.0 & 22.6 & 27.5 & 10.1 & $<0.001$ \\
\hline$\geq 80$ years & 106.2 & 99.9 & 94.3 & 150.0 & 199.3 & 273.3 & 324.3 & 307.5 & 418.1 & 397.5 & 18.4 & $<0.001$ \\
\hline \multicolumn{13}{|c|}{ State capitals in the Central * } \\
\hline 60-79 years & 9.4 & 15.5 & 16.0 & 23.4 & 10.0 & 26.0 & 21.8 & 31.2 & 29.5 & 31.8 & 11.8 & 0.006 \\
\hline$\geq 80$ years & 86.8 & 144.5 & 212.0 & 287.0 & 329.8 & 332.0 & 311.9 & 482.8 & 453.0 & 567.8 & 17.7 & $<0.001$ \\
\hline \multicolumn{13}{|l|}{ Brasília } \\
\hline 60-79 years & 7.4 & 5.3 & 16.7 & 14.1 & 14.8 & 21.8 & 21.8 & 23.0 & 23.3 & 17.8 & 13.0 & 0.007 \\
\hline$\geq 80$ years & 57.4 & 93.3 & 111.4 & 207.6 & 290.4 & 235.1 & 392.5 & 383.1 & 424.5 & 389.6 & 21.6 & $<0.001$ \\
\hline \multicolumn{13}{|l|}{ Belo Horizonte } \\
\hline $60-79$ years & 16.1 & 26.2 & 18.0 & 29.3 & 22.4 & 35.5 & 36.4 & 37.2 & 38.1 & 35.5 & 8.8 & 0.003 \\
\hline$\geq 80$ years & 153.1 & 242.3 & 315.3 & 379.7 & 505.1 & 495.6 & 615.8 & 592.1 & 613.6 & 607.2 & 14.2 & $<0.001$ \\
\hline \multicolumn{13}{|l|}{ Rio de Janeiro } \\
\hline $60-79$ years & 17.4 & 18.3 & 22.8 & 20.7 & 22.3 & 26.1 & 25.9 & 28.7 & 36.5 & 34.6 & 7.9 & $<0.001$ \\
\hline$\geq 80$ years & 129.0 & 174.1 & 190.5 & 183.3 & 254.0 & 304.1 & 311.6 & 412.9 & 455.0 & 491.3 & 14.8 & $<0.001$ \\
\hline \multicolumn{13}{|l|}{ São Paulo } \\
\hline 60-79 years & 17.4 & 23.3 & 23.7 & 22.5 & 27.7 & 29.7 & 33.4 & 36.3 & 33.5 & 35.6 & 7.5 & $<0.001$ \\
\hline$\geq 80$ years & 170.4 & 242.8 & 287.7 & 300.8 & 399.7 & 458.0 & 561.8 & 583.6 & 629.8 & 693.1 & 15.5 & $<0.001$ \\
\hline \multicolumn{13}{|l|}{ Vitória } \\
\hline 60-79 years & 22.3 & 29.0 & 48.9 & 33.7 & 26.1 & 24.9 & 66.0 & 63.8 & 45.8 & 61.2 & 9.5 & 0.030 \\
\hline$\geq 80$ years & 179.0 & 336.1 & 434.5 & 408.8 & 524.9 & 618.1 & 642.9 & 836.2 & 749.3 & 867.2 & 14.9 & $<0.001$ \\
\hline \multicolumn{13}{|l|}{ Curitiba } \\
\hline 60-79 years & 14.5 & 11.3 & 29.9 & 18.2 & 16.2 & 23.4 & 29.2 & 28.0 & 21.9 & 36.2 & 8.7 & 0.021 \\
\hline$\geq 80$ years & 169.2 & 305.4 & 320.3 & 323.6 & 476.7 & 402.8 & 571.1 & 588.7 & 678.0 & 621.0 & 13.3 & $<0.001$ \\
\hline \multicolumn{13}{|l|}{ Florianópolis } \\
\hline $60-79$ years & - & 33.8 & 44.8 & 18.2 & 11.5 & 10.7 & 5.1 & 19.3 & 34.0 & 27.9 & -3.8 & 0.698 \\
\hline$\geq 80$ years & 286.8 & 266.2 & 355.3 & 265.6 & 465.9 & 367.9 & 502.6 & 371.4 & 392.9 & 441.1 & 5.2 & 0.028 \\
\hline \multicolumn{13}{|l|}{ Porto Alegre } \\
\hline $60-79$ years & 15.1 & 29.1 & 40.8 & 32.0 & 46.1 & 45.5 & 51.4 & 40.2 & 45.0 & 44.0 & 8.5 & 0.020 \\
\hline$\geq 80$ years & 220.7 & 277.9 & 322.9 & 367.9 & 535.9 & 628.7 & 595.1 & 771.1 & 717.8 & 720.6 & 14.1 & $<0.001$ \\
\hline \multicolumn{13}{|l|}{ All state capitals } \\
\hline $60-79$ years & 14.3 & 18.2 & 20.7 & 19.8 & 22.0 & 26.6 & 28.7 & 29.5 & 30.2 & 31.8 & 8.4 & $<0.001$ \\
\hline$\geq 80$ years & 135.5 & 182.0 & 209.1 & 233.7 & 315.3 & 363.4 & 426.0 & 464.6 & 511.1 & 540.7 & 15.5 & $<0.001$ \\
\hline
\end{tabular}

* Except Brasília.

the elderly population, various countries have reported a reduction in mortality from these causes. In the United States, Alzheimer's disease is the fifth leading cause of death in the population 65 years and older. From 2000 to 2008, while mortality from cardiovascular diseases, stroke, and prostate cancer were decreasing by $13 \%$, $20 \%$, and $8 \%$, respectively, Alzheimer's disease increased by $66 \% 31$.

Understanding the increase in mortality from Alzheimer's disease poses major challenges. Population aging and the supply of diagnostic 
Table 4

Mortality rate in men (per 100,000 inhabitants) with Alzheimer's disease recorded on the Death Certificate and percent annual variation by age groups and state capitals. Brazil, 2000-2009.

\begin{tabular}{|c|c|c|c|c|c|c|c|c|c|c|c|c|}
\hline Capitals/Regions & 2000 & 2001 & 2002 & 2003 & 2004 & 2005 & 2006 & 2007 & 2008 & 2009 & $\begin{array}{c}\text { Annual } \\
\text { variation } \\
\text { (\%) }\end{array}$ & p-value \\
\hline \multicolumn{13}{|c|}{ State capitals of the North } \\
\hline $60-79$ years & 6.3 & 3.5 & 13.1 & 4.2 & 6.0 & 14.0 & 12.4 & 8.4 & 21.2 & 17.9 & 14.5 & 0.020 \\
\hline$\geq 80$ years & - & 50.3 & 13.8 & 63.0 & 102.2 & 125.5 & 178.0 & 140.4 & 195.8 & 280.6 & 28.3 & 0.003 \\
\hline \multicolumn{13}{|l|}{ State capitals of the } \\
\hline \multicolumn{13}{|l|}{ Northeast } \\
\hline $60-79$ years & 15.7 & 15.3 & 12.2 & 15.3 & 15.7 & 19.9 & 19.9 & 21.8 & 27.8 & 23.4 & 7.1 & 0.001 \\
\hline$\geq 80$ years & 80.2 & 116.9 & 135.9 & 147.7 & 185.7 & 225.3 & 274.4 & 312.0 & 420.0 & 418.8 & 18.2 & $<0.001$ \\
\hline \multicolumn{13}{|c|}{ State capitals of the Central * } \\
\hline $60-79$ years & 8.3 & 9.3 & 23.7 & 25.5 & 27.0 & 26.6 & 32.6 & 34.5 & 27.0 & 30.2 & 13.1 & 0.007 \\
\hline$\geq 80$ years & 57.7 & 27.2 & 205.4 & 279.3 & 298.9 & 288.2 & 312.9 & 391.8 & 296.9 & 512.5 & 24.2 & 0.006 \\
\hline \multicolumn{13}{|l|}{ Brasília } \\
\hline $60-79$ years & 4.4 & 6.2 & 7.8 & 11.1 & 14.1 & 21.3 & 25.0 & 13.4 & 13.8 & 22.3 & 15.6 & 0.003 \\
\hline$\geq 80$ years & 133.3 & 147.5 & 22.7 & 167.8 & 368.9 & 316.1 & 438.5 & 300.7 & 311.4 & 339.3 & 17.7 & 0.058 \\
\hline \multicolumn{13}{|l|}{ Belo Horizonte } \\
\hline $60-79$ years & 15.2 & 20.4 & 25.6 & 34.0 & 24.8 & 37.5 & 35.0 & 31.6 & 23.9 & 36.0 & 6.3 & 0.040 \\
\hline$\geq 80$ years & 278.4 & 239.5 & 289.6 & 475.3 & 467.4 & 418.3 & 512.0 & 586.1 & 488.8 & 626.7 & 9.7 & 0.001 \\
\hline \multicolumn{13}{|l|}{ Rio de Janeiro } \\
\hline $60-79$ years & 15.9 & 17.6 & 19.7 & 20.7 & 22.7 & 21.9 & 28.0 & 29.4 & 35.8 & 32.5 & 8.7 & $<0.001$ \\
\hline$\geq 80$ years & 143.5 & 165.7 & 185.6 & 209.3 & 258.4 & 282.1 & 340.0 & 308.1 & 336.9 & 429.8 & 11.5 & $<0.001$ \\
\hline \multicolumn{13}{|l|}{ São Paulo } \\
\hline $60-79$ years & 13.7 & 23.3 & 24.1 & 23.4 & 29.1 & 32.3 & 32.1 & 35.2 & 31.4 & 35.8 & 8.3 & 0.001 \\
\hline$\geq 80$ years & 174.1 & 199.5 & 225.6 & 286.6 & 392.7 & 433.1 & 431.6 & 471.4 & 559.2 & 633.9 & 14.5 & $<0.001$ \\
\hline \multicolumn{13}{|l|}{ Vitória } \\
\hline $60-79$ years & 10.6 & 29.8 & 28.5 & 36.5 & 52.5 & 24.9 & 23.9 & 53.4 & 29.9 & 28.9 & 6.2 & 0.238 \\
\hline$\geq 80$ years & 708.6 & 281.8 & 436.7 & 81.3 & 454.1 & 904.6 & 518.3 & 482.9 & 517.3 & 538.5 & 5.2 & 0.508 \\
\hline \multicolumn{13}{|l|}{ Curitiba } \\
\hline $60-79$ years & 18.1 & 25.9 & 7.1 & 27.2 & 27.6 & 30.6 & 17.6 & 29.4 & 39.4 & 23.5 & 6.8 & 0.211 \\
\hline$\geq 80$ years & 163.7 & 190.5 & 214.1 & 267.2 & 422.2 & 531.8 & 470.7 & 516.3 & 572.9 & 685.2 & 16.3 & $<0.001$ \\
\hline \multicolumn{13}{|l|}{ Florianópolis } \\
\hline $60-79$ years & 27.6 & 25.0 & 31.5 & 22.3 & 42.4 & 19.5 & 12.3 & 11.7 & 35.2 & 22.5 & -4.2 & 0.391 \\
\hline$\geq 80$ years & 359.4 & 333.0 & 465.8 & 217.2 & 338.1 & 368.9 & 286.8 & 643.1 & 795.8 & 250.4 & 3.3 & 0.496 \\
\hline \multicolumn{13}{|l|}{ Porto Alegre } \\
\hline $60-79$ years & 24.0 & 25.7 & 46.5 & 40.3 & 32.8 & 39.1 & 46.7 & 52.4 & 38.0 & 39.9 & 5.2 & 0.057 \\
\hline$\geq 80$ years & 320.1 & 416.4 & 375.3 & 455.1 & 537.7 & 577.5 & 638.7 & 747.3 & 708.7 & 658.8 & 8.9 & $<0.001$ \\
\hline \multicolumn{13}{|l|}{ All state capitals } \\
\hline 60-79 years & 14.3 & 18.0 & 20.0 & 21.2 & 23.0 & 26.0 & 27.0 & 28.6 & 29.9 & 29.8 & 7.7 & $<0.001$ \\
\hline$\geq 80$ years & 144.5 & 166.0 & 192.7 & 235.7 & 305.1 & 335.8 & 369.3 & 393.3 & 443.0 & 504.7 & 14 & $<0.001$ \\
\hline
\end{tabular}

* Except Brasília.

methods and improved professional training for diagnosis of the disease explain this increase, but the reduction in the prevalence of the principal risk factors, the persistent stigma associated with the disease, and the view that Alzheimer's is part of the natural aging process would appear to act in the opposite direction 32 . However, the increase in mortality from Alzheimer's disease has been observed in both high and middle-income countries. A systematic review of incidence, prevalence, and mortality from Alzheimer's disease in China concluded that the burden of the 
Underlying cause of mortality in individuals 60 years and older with and without Alzheimer's disease recorded on the death certificate, according to gender. State capitals of Brazil, 2000-2009.

\begin{tabular}{|c|c|c|c|c|c|c|c|c|c|c|}
\hline \multirow[t]{3}{*}{ Underlying cause } & \multicolumn{5}{|c|}{ Men } & \multicolumn{5}{|c|}{ Women } \\
\hline & \multicolumn{2}{|c|}{$\begin{array}{c}\text { With Alzheimer's } \\
\text { disease }\end{array}$} & \multicolumn{2}{|c|}{$\begin{array}{c}\text { Without Alzheimer's } \\
\text { disease }\end{array}$} & \multirow[t]{2}{*}{$p$-value } & \multicolumn{2}{|c|}{$\begin{array}{c}\text { With Alzheimer's } \\
\text { disease }\end{array}$} & \multicolumn{2}{|c|}{$\begin{array}{c}\text { Without Alzheimer's } \\
\text { disease }\end{array}$} & \multirow[t]{2}{*}{$p$-value } \\
\hline & $\mathrm{n}$ & $\%$ & $\mathrm{n}$ & $\%$ & & $\mathrm{n}$ & $\%$ & $\mathrm{n}$ & $\%$ & \\
\hline Respiratory diseases & 520 & 13.6 & 100.336 & 13.0 & 0.617 & 643 & 8.9 & 108.630 & 14.0 & $<0.001$ \\
\hline Neoplasms & 389 & 10.2 & 144.954 & 20.3 & $<0.001$ & 552 & 7.6 & 134.331 & 17.4 & $<0.001$ \\
\hline $\begin{array}{l}\text { Ischemic heart } \\
\text { diseases }\end{array}$ & 471 & 12.4 & 95.890 & 13.4 & 0.084 & 994 & 13.7 & 91.523 & 11.8 & $<0.001$ \\
\hline Stroke & 564 & 14.8 & 80.127 & 11.2 & $<0.001$ & 1.121 & 15.5 & 97.125 & 12.6 & $<0.001$ \\
\hline Diabetes mellitus & 273 & 7.2 & 34.753 & 4.9 & $<0.001$ & 571 & 7.9 & 49.223 & 6.4 & $<0.001$ \\
\hline Falls & 32 & 0.8 & 5.789 & 0.8 & 0.801 & 82 & 1.1 & 6.219 & 0.8 & 0.001 \\
\hline
\end{tabular}

disease is underestimated there and that the real growth rate is $20 \%$ higher than estimates by international health agencies 33 . In addition, new theories have appeared to explain the increase in Alzheimer's disease. A study in 10 developed countries (Australia, Canada, Italy, Netherlands, Spain, United Kingdom, United States, Germany, Japan, and France), where vital statistics are more accurate, also showed an increase in mortality. In this case, changes in the behavior of the disease are attributed more to epigenetic factors than to an increase in longevity 14 . Thus, new horizons are opening for understanding the disease, glimpsed in studies on multicausality to explain its evolution.

We should point out that not all chronic conditions are more prevalent in Alzheimer's patients. There is evidence of its protective effect against the development of cancer. A prospective population-based study found lower cancer incidence in persons with Alzheimer's disease, in addition to a reduced risk of Alzheimer's disease among persons with neoplasms ${ }^{34}$. Other studies have also failed to demonstrate an association between cancer and dementias, including dementia from Alzheimer's disease, indicating that specific factors are associated with the neurodegenerative disease 35,36 .

Diabetes mellitus and stroke share common risk factors with Alzheimer's disease, and in this study they were closely associated in the analysis of deaths from the perspective of multiple causes of mortality, consistent with international studies. Meanwhile, neoplasms were more common among individuals without Alzheimer's disease.

Like all other chronic diseases, the reduction in mortality from Alzheimer's disease requires a reduction in the associated risk factors. Physical co-morbidities contribute to cognitive and functional decline and have important implications for healthcare providers, since these patients require access to specialized services.

Strategies to achieve this goal include improved access to health services, strengthening comprehensive care for patients in all age brackets, and training of health workers on aging. Improving the patients' quality of life involves support for persons with Alzheimer's disease and their caregivers 37. The results of Brazilian National Household Sample Survey (PNAD) 26 show positive trends in health conditions and use of healthcare services by the elderly Brazilian population, with an increase in the number of physician visits and improvement in self-rated health 38 .

Despite the consistency between the current study and research in other countries, the study presents some limitations. When using a database with secondary data on mortality, even with international standardization in coding causes of death, there is still the problem of underreporting and underrecording of deaths 39 .

Completeness of information on the death certificate is another factor to consider in mortality studies. It is common to record only the consequences of a preexisting disease, leaving out important events that led to the immediate cause of death. This is a particularly important limitation in the elderly population, given the existence of various co-morbidities, potentially leading to underreporting, especially of long-lasting chronic and degenerative diseases 40 .

The study design strategy of analyzing deaths with Alzheimer's disease as the underlying cause 
and as cause recorded on the death certificate aimed to capture the magnitude of the disease in Brazil more accurately, closer to a more comprehensive and true picture of the situation, besides simultaneously considering other diseases present in the these elderly individuals. Still, one cannot guarantee that the information on Alzheimer's disease is recorded correctly in all situations, and there may be classification errors involving other forms of dementia. Representative observational studies of the Brazilian population are needed to respond to the demands for new knowledge on this disease in the country.

Meanwhile, the study's strengths include the production of information on Alzheimer's disease in Brazil using recent data and a broad nationwide approach, in a context of near absence of previous similar research.

\section{Resumen}

La enfermedad de Alzheimer es la demencia más frecuente entre adultos mayores en el mundo. Para evaluar la evolución de la mortalidad por la enfermedad de Alzheimer en Brasil, se ha desarrollado un estudio con datos del Sistema de Información sobre Mortalidad del Ministerio de Salud, durante el período 2000-2009. Se calcularon las tasas de mortalidad estandarizadas por edad y sexo en las capitales brasileñas y se registró la variación porcentual mediante ajuste de la regresión exponencial. El conjunto de las capitales presentó un aumento anual de las tasas de mortalidad en el grupo de edad de 60 a 79 años, de un 8,4\% en mujeres y un 7,7\% en hombres. En el grupo de 80 o más años, el aumento fue de un 15,5\% en mujeres y un $14 \%$ en hombres. No obstante, hubo una disminución en la tasa de mortalidad por todas las causas entre los adultos mayores de ambos sexos. Se destaca un aumento de la mortalidad por enfermedad de Alzheimer en el contexto de las enfermedades crónicas como un proxy para la prevalencia de la enfermedad en la población, y se indican estrategias de asistencia en el cuidado de pacientes con enfermedades de larga duración.

Enfermedad de Alzheimer; Demencia; Anciano; Mortalidad

\section{Contributors}

J. B. Teixeira participated in the study conceptualization and design, data analysis, and writing of the article. P. R. B. Souza Junior and M. M. Theme Filha participated in the study design, data analysis, and writing and critical revision of the article. J. Higa participated in the data analysis and writing of the article. 


\section{References}

1. Wong LLR, Carvalho JA. O rápido processo de envelhecimento populacional do Brasil: sérios desafios para as políticas públicas. Rev Bras Estud Popul 2006; 23:5-26.

2. Schmidt MI, Duncan BB, Silva GA, Menezes AM, Monteiro CA, Barreto SM, et al. Chronic non-communicable diseases in Brazil: burden and current challenges. Lancet 2011; 377:1949-61.

3. Fratiglioni L, Launer LJ, Andersen K, Breteler MM, Copeland JR, Dartigues JF, et al. Incidence of dementia and major subtypes in Europe: a collaborative study of population-based cohorts. Neurology 2000; 54(11 Suppl 5):S10-5.

4. Wimo A, Winblad B, Jönsson L. The worldwide societal costs of dementia: estimates for 2009. Alzheimers Dement 2010; 6:98-103.

5. Qiu C. Preventing Alzheimer's disease by targeting vascular risk factors: hope and gap. J Alzheimers Dis 2012; 32:721-31.

6. Singer RB. Mortality derived from 5-year survival in patients with Alzheimer disease. J Insur Med 2005; 37:264-71.

7. Helzner EP, Scarmeas N, Cosentino S, Tang MX, Schupf N, Stern Y. Survival in Alzheimer disease: a multiethnic, population-based study of incident cases. Neurology 2008; 71:1489-95.

8. Reitz C, Brayne C, Mayeux R. Epidemiology of Alzheimer disease. Nat Rev Neurol 2011; 7:137-52.

9. Karch CM, Goate AM. Alzheimer's disease risk genes and mechanisms of disease pathogenesis. Biol Psychiatry 2014; 77:43-51.

10. Chi S, Yu JT, Tan MS, Tan L. Depression in Alzheimer's disease: epidemiology, mechanisms, and management. J Alzheimers Dis 2014; 42:739-55.

11. Frota NAF, Nitrini R, Damasceno BP, Forlenza O, Dias-Tosta E, da Silva AB, et al. Critérios para o diagnóstico de doença de Alzheimer. Dement Neuropsychol 2011; 5 Suppl 1:5-10.

12. Brookmeyer R, Corrada MM, Curriero FC, Kawas C. Survival following a diagnosis of Alzheimer disease. Arch Neurol 2002; 59:1764-7.

13. Rountree SD, Chan W, Pavlik VN, Darby EJ, Doody RS. Factors that influence survival in a probable Alzheimer disease cohort. Alzheimers Res Ther 2012; 15:16.

14. Pritchard C, Mayers A, Baldwin D. Changing patterns of neurological mortality in the 10 major developed countries - 1979-2010. Public Health 2013; 127:357-68.

15. Rocca WA, Petersen RC, Knopman DS, Hebert LE, Evans DA, Hall KS, et al. Trends in the incidence and prevalence of Alzheimer's disease, dementia, and cognitive impairment in the United States. Alzheimers Dement 2011; 7:80-93.

16. Brosselin P, Duport N, Bloch J. Mortality with Alzheimer's disease and dementia in France, 2006 Rev Epidemiol Sante Publique 2010; 58:269-76.

17. Steenland K, MacNeil J, Vega I, Levey A. Recent trends in Alzheimer's disease mortality in the United States, 1999-2004. Alzheimer Dis Assoc Disord 2009; 23:165-70.

18. Hallberg O. Is increased mortality from Alzheimer's disease in Sweden a reflection of better diagnostics? Curr Alzheimer Res 2009; 6:471-5.
19. Fagundes SD, Silva MT, Thees MFRS, Pereira MG Prevalence of dementia among elderly Brazilians: a systematic review. São Paulo Med J 2011; 129:4650 .

20. Ribeiro PCC, Lopes CS, Lourenço RA. Prevalence of dementia in elderly clients of a private health care plan: a study of the FIBRA-RJ, Brazil. Dement Geriatr Cogn Disord 2013; 35:77-86.

21. Pinto MF, Barbosa DA, Ferreti CEL, Souza LF, Fram DS, Belasco AGS. Qualidade de vida de cuidadores de idosos com doença de Alzheimer. Acta Paul Enferm 2009; 22:652-7.

22. Szwarcwald CL, Morais-Neto OL, Frias PG, Souza Junior PRB, Escalante JJC, Lima RB, et al. Busca ativa de óbitos e nascimentos no Nordeste e na Amazônia Legal: estimação das coberturas do SIM e do Sinasc nos municípios brasileiros. In: Núcleo de Comunicação, Coordenação Geral de Informação e Análise Epidemiológica, Departamento de Análise de Situação em Saúde, Secretaria de Vigilância em Saúde, Ministério da Saúde, organizador. Saúde Brasil 2010: uma análise da situação de saúde e de evidências selecionadas de impacto de ações de vigilância em saúde. Brasília: Ministério da Saúde; 2011. p. 79-98.

23. Moschetti K, Cummings P, Sorvillo F, Kuo T. Burden of Alzheimer's disease-related mortality in the United States, 1999-2008. J Am Geriatr Soc 2012; 60:1509-14

24. Griffiths C, Rooney C. Trends in mortality from Alzheimer's disease, Parkinson's disease and dementia, England and Wales, 1979-2004. Health Stat Q 2006; 30:6-14

25. Mohamed H, Afonso C, Avilan R, Jose M. Tasa de mortalidad específica, según género y edad, de la enfermedad de Alzheimer en Venezuela. Gac Méd Caracas 2002; 110:512-6.

26. Instituto de Pesquisa Econômica Aplicada. PNAD-2007 primeiras análises: demografia e gênero. Rio de Janeiro: Instituto de Pesquisa Econômica Aplicada; 2008. (Comunicados da Presidência, 11).

27. Sinforiani E, Citterio A, Zucchella C, Bono G, Corbetta S, Merlo P, et al. Impact of gender differences on the outcome of Alzheimer's disease. Dement Geriatr Cogn Disord 2010; 30:147-54.

28. Leibson CL, Rocca WA, Hanson VA, Cha R, Kokmen E, O'Brien PC, et al. Risk of dementia among persons with diabetes mellitus: a population-based cohort study. Am J Epidemiol 1997; 145:301-8.

29. Götz J, Ittner LM, Lim YA. Common features between diabetes mellitus and Alzheimer's disease. Cell Mol Life Sci 2009; 66:1321-5.

30. Ukraintseva S, Sloan F, Arbeev K, Yashin A. Increasing rates of dementia at time of declining mortality from stroke. Stroke 2006; 37:1144-5.

31. Thies W, Bleiler L. 2012 Alzheimer's disease facts and figures. Alzheimers Dement 2012; 8:131-68.

32. Alzheimer's Disease International. World Alzheimer report 2010. The global economic impact of dementia. http://www.alz.co.uk/research/files/ WorldAlzheimerReport2010.pdf (accessed on 04/ Jun/2014). 
33. Chan KY, Wang W, Wu JJ, Theoduratou E, Car J, Middleton L, et al. Epidemiology of Alzheimer's disease and other forms of dementia in China 1990-2010: a systematic review. Lancet 2013; 381:2016-20.

34. Driver JA, Beiser A, Au R, Kreger BE, Splansky GL, Kurth T, et al. Inverse association between cancer and Alzheimer's disease: results from the Framingham Heart Study. BMJ 2012; 344:e1442.

35. Benito-León J, Romero JP, Louis ED, BermejoPareja F. Faster cognitive decline in elders without dementia and decreased risk of cancer mortality: NEDICES Study. Neurology 2014; 82:1441-8.

36. Romero JP, Benito-León J, Louis ED, BermejoPareja F. Alzheimer's disease is associated with decreased risk of cancer-specific mortality: a prospective study (NEDICES). J Alzheimers Dis 2014; 40:465-73.
37. Kanso S, Romero DE, Leite IC, Marques A. A evitabilidade de óbitos entre idosos em São Paulo, Brasil: análise das principais causas de morte. Cad Saúde Pública 2013; 29:735-48.

38. Mello Jorge MHP, Laurenti R, Lima-Costa MF, Gotlieb SLD, Chiavegatto Filho ADP. A mortalidade de idosos no Brasil: a questão das causas mal definidas. Epidemiol Serv Saúde 2008; 17:271-81.

39. Ministério da Saúde. Saúde Brasil 2004. Uma análise da situação de saúde. Brasília: Ministério da Saúde; 2004

40. Instituto Brasileiro de Geografia e Estatística. Indicadores sociodemográficos e de saúde no Brasil, 2009. http://www.ibge.gov.br/home/estatistica/ populacao/indic_sociosaude/2009/indicsaude. pdf (accessed on 24/Mar/2013).

Submitted on 09/Aug/2013

Final version resubmitted on 23/Jul/2014

Approved on 29/Sep/2014 